\title{
The Accreditation Issues of Private Universities in Malawi
}

\author{
Samson C. R. KAJAWO ${ }^{1 *}$ and Xiuhua DONG $^{2}$ \\ ${ }^{1}$ International Center for Teacher Education, East China Normal University, \\ 500 Dongchuan Road, Minhang District, Shanghai, P.R. China. \\ ${ }^{2}$ Higher Education Research Institute, Shanghai Academy of Education Science, Shanghai, P.R. China \\ *Corresponding author email: samsonkajawo@gmail.com
}

Received: 06 August 2020 / Revised: 31 October 2020 / Accepted: 24 November 2020 / Published: 06 December 2020

\begin{abstract}
This article analyses the perceptions of various stakeholders regarding their views on how accreditation issues were affecting private universities' operations in Malawi. The article was based on a study that was conducted at six private universities in Malawi using a mixed methods research approach, utilising a descriptive survey research design. It involved a total of 152 respondents comprising of registrars, heads of departments, teachers and students from the targeted private universities, as well as public and private sectors executives in the country. This study revealed that the majority of the respondents were of the view that Malawi National Council for Higher Education was doing a commendable job in providing the needed monitoring and evaluation of higher education institutions and their respective study programmes in Malawi. It was also revealed that the action of being discredited or deregistered had a very big impact on the reputation of the concerned universities, students and the already produced graduates, hence the visits by NCHE officials created tension at the institutions. Nevertheless, the study concluded that the accreditation of institutions of higher learning and their study programmes was the only way to go in enhancing and controlling the quality of higher education in Malawi since there is no alternative to strict compliance to high standards. The need for revision of the higher education policies and laws in the country to strongly discourage the operation of the institution prior to their registration and accreditation by NCHE is strongly recommended.
\end{abstract}

Keywords: Accreditation, private universities, Malawi, higher education, NCHE.

\section{Introduction}

\subsection{Background}

It is indisputable fact that there has been a rapid growth in the number of private universities in Africa and other continents. This is because more and more people around the world have realised the importance of investing in education (Mbirithi, 2013). Development of the university education sector has, therefore, become a priority in the most advanced as well as in emergent economies. Prior to 1994, the private sector could not offer higher education services in Malawi due to strict government regulations and policies which were primarily aimed at controlling the quantitative output of graduates (Chivwara, 2013). The focus was on quality, not quantity. For instance, Chivwara indicates that the Roman Catholic Church intended to establish a university as far back as 1964, but it was not possible due to government restrictions.

In 2006, the Government of Malawi decided to come up with a liberalization policy of higher education in response to the rising demand for higher education among the people in the country (Kajawo, 2019; Shawa, 2014). By 2009, there were only four private universities in Malawi (World Bank, 2009). But the figure escalated sharply to 18 in 2017 (National Council for Higher Education [NCHE], 2017). The number of private universities grew to 41 in 2018, which later dropped to 32 after the government's higher education monitoring agency (National Council for Higher Education) ordered nine of them to close down since they failed to fulfil the basic requirements stipulated by the council for a university to be duly registered and

Copyright (C) 2020. The Author(s). Published by AIJR Publisher.

This is an open access article under Creative Commons Attribution-NonCommercial 4.0 International (CC BY-NC 4.0) license, which permits any non-commercial use, distribution, adaptation, and reproduction in any medium, as long as the original work is properly cited. 
accredited for operation in Malawi. In 2018, the number of registered private universities was 28 (Kajawo, 2019; National Council for Higher Education [NCHE], 2018). In 2019, National Council for Higher Education in Malawi announced 26 private universities in Malawi as duly or provisionally registered, while only 13 of them were declared accredited (NCHE, 2019).

According to NCHE's accreditation and evaluation framework, higher education institution's accreditation specifically evaluates physical, human, financial, teaching and learning resources, management and operational procedures and the environment against an acceptable standard of academic life. On the other hand, individual study programme accreditation evaluates the academic qualifications of all members of staff employed by that particular higher education institution during the period of assessment, the total number of students enrolled, ICT infrastructure and the provision for training, the library and other teaching and learning resources, the institution's financial resources, the physical facilities, student-staff ratio, and the curriculum issues for each programme (NCHE, 2018). In line with its mandate, NCHE has been registering, accrediting as well as deregistering and denying accreditation and rejecting registration of some institutions (Muheya, 2016; NCHE, 2017; Nyondo, 2015). For instance, NCHE indicated that the irregularity of the institution and misrepresentation of facts as the main reasons for the withdrawal of license Africa University in 2016. In 2020, the council released a list of programmes of study which were accredited in only 14 private universities and another list of programmes that failed the accreditation from nine private universities, which unfortunately left two private universities with no programme of study accredited for their institutions (NCHE, 2020).

Media had been awash with stories of closure and non-accrediting of some private universities in Malawi due to the reason that they were failing to meet minimum requirements for a university as per the National Council of Higher Education regulations (Muheya, 2016; Nyondo, 2015). However, nothing or little had been seriously done to understand these accreditation issues and how they affect the Malawians' choices of enrolling in those privately owned higher education institutions in the country. This article presents part of the findings of the Masters of Education research study undertaken in 2018 which was aimed at examining the performance and challenges of private universities in Malawi. In this article, the focus is on presenting the findings on how accreditation issues were affecting private universities' operations in Malawi in 2018. The article specifically focuses on presenting the perceptions of key stakeholders of private universities in Malawi on issues of accreditation.

\subsection{Literature review}

Research on private higher education is extensive. Current studies all over the world have focused on determining the management, performance and the contributions of private universities to the development of university education in various countries, as well as the challenges they are facing (Ajadi, 2010; Akpotu \& Akpochafo, 2009; Amponsah \& Onuoha, 2013; Garwe, 2015; Mande, 2006; Mbirithi, 2013; Mwebi \& Simatwa, 2013; Ochwa-echel, 2016; Onsongo, 2007; Suleiman, Hanafi \& Tanslikhan, 2017; Tibarimbasa, 2010). Other studies have also sought to explore various policies related to university accessibility, staff management and accreditation (e.g. Chivwara, 2013; Harvey, 2004; Hayward, 2006; Hunter, 2009; Lenns, 2003; Mapolisa, 2015; Scheele, 2004; Seniwoliba \& Yakubu, 2015). It is fascinating to note that consistently running throughout virtually all of this literature is the premise that private education has become to be the most important aspect of global education, making issues of quality control and assurance essential than ever. Several studies have also been done on higher education institutions in Malawi, most of them focusing on higher education access policies especially on public universities (e.g. Chimombo, 2003; Chivwara, 2013; Gomile-Chidyaonga, 2003; Macjessie-Mbewe, 2004; Nur-Awaleh \& Mtegha, 2005; Shawa, 2014), and very few on private universities (Kajawo, 2019).

It is now clear that the growth in the number of private universities in Africa and other continents awakened governments to set control and monitoring measures through specific policies and regulations. In most African countries, the government legalization and recognition of provision of higher education by private sectors are done through national legislation; that is, the parliamentary process of enacting a bill into law. 
Samson C. R. KAJAWO \& Xiuhua DONG, Adv. J Social Sci.; Vol. 7, Issue 1, pp: 125-137, 2020

The law, therefore, in most instances, gives power to a specific regulatory body to oversee the accreditation, quality control and licensing processes of private universities in the respective countries (Mande, 2006; Ochwa-Echel, 2016).

Scholars have provided various definitions of the term "accreditation". Lyamtane (2013) defined "accreditation" as a process of recognising a university through the assessment of its academic and professional programmes as well as its governance and management structures based on a particular level of required performance, integrity, standards and quality which entitles the university to the confidence of the public it serves. To Lenns (2003), the term "accreditation" refers to an assessment of whether a university qualifies for a certain status in line with the required standards for national systems of quality assurance. In many countries, the term "accreditation" is used to refer to a legal process of authorizing particular universities to operate under the authority of a particular Act of Parliament, statue or decree (Hayward, 2006). Shankar (2016) describes accreditation as a process of assessing the performance of institutions of higher learning that volunteer to be accredited, based on, among many things, the curriculum, infrastructure and learning resources, leadership and management, teaching-learning evaluation, innovations as well as students' support and performance.

According to Lenns (2003), accreditation asks the question "are you good enough to be approved to confer degrees?" (p. 7). Therefore, accreditation examines institutions as well as their programmes of study if they have educationally appropriate objectives, financial, human and physical resources needed to achieve the objectives. It also assesses if the institution demonstrates that it is achieving the objectives, and if it provides sufficient evidence that it will continue to achieve those objectives for some reasonable time into the future (Lenn, 2003). In many countries, accreditation is expected to be done periodically (in every 5 to 10 years) by an agency within Ministry of Education, while in some countries, for instance, the United States of America, it is done by autonomous quality assurance agencies that are non-governmental in nature (Hayward, 2006). In India, Shankar (2016) indicates that there are two higher education regulatory agencies which work together, which are the "National Assessment and Accreditation Council" and "The National Board of Accreditation". According to him, the National Assessment and Accreditation Council is an autonomous body established in 1994 to ensure quality education through assessment and accreditation of higher education institutions, while the National Board of Accreditation was established under the Parliamentary Act of 1987 to specifically conduct assessment or accreditation of a technical institution or program and initiating the processes of developing mechanisms for quality assessment. In this respect, both the Council and the Board, accredit public and private higher education institutions (Shankar, 2016).

In Japan, Maruyama (2008) reports that private higher education institutions, despite their autonomous status, are still under the strict supervision and control of the education ministry, especially with the regulation of the guiding document; "Standard for the Establishment of Universities", which specifies the many rules that universities must abide-by when seeking Ministry's approval to establish or expand a university. The legislation stipulates the standard that university must meet, for example, in terms of the number of students, degree requirements of academic staff, number of teachers, number of books in the library, square footage of the campus building per student, and many more. It usually takes several years to satisfy these requirements and open a new university.

Many scholars have also written on the existence of accreditation agencies in African countries. For example, in Uganda, the Ugandan Parliament passed the "Universities and Other Tertiary Institutions Act" in the year 2001. The Act among other things established the National Council for Higher Education (NCHE) as a regulatory agency, with a mission to come up with standards and regulations of ensuring that both public and private institutions of higher learning in Uganda provide and maintain appropriate and excellence higher education for all qualified Ugandans (Ochwa-Echel, 2016). Some of the main responsibilities of the council are to create a higher education accreditation system, to establish university national admission standards and to ensure that institutions of higher learning have adequate physical structures and facilities. If satisfied, the council recommends for provision of a charter which is signed by the State President, which enables the university to be accredited (Uganda National Council for Higher 
Education, 2011). In Nigeria, the National Universities Commission (NUC) is the body that has the responsibility of assessing and controlling the quality of higher education in the country. According to Ajadi (2010), among other things, the Nigerian National Universities Commission set the requirements to be met by higher education institutions as well as their programmes of study being offered to be accredited.

Despite having these regulatory bodies in place, studies have revealed that there were a lot of challenges related to accreditation and monitoring processes and policies of higher education in African countries. In Uganda, Ochwa-Echel (2016) find out that, all four universities included in his study were accredited, while only two of them were chartered, this made the researcher fail to understand how they received accreditation without charters. This was one of the challenges that were found in the accreditation system in Uganda. According to this author, these two unchartered universities, though they had provisional licenses, lacked necessary resources in terms of funds, facilities such as classrooms, library, faculty offices as well as full-time academic staff as per the requirements of the Uganda National Council for Higher Education.

In Kenya, Gogo (2010) found that in 2010 private universities were enrolling students into study programs that were not recognized as offering proper qualifications to the various disciplines since they were not accredited by Commission for Higher Education. According to this researcher, this was equivalent to extorting students' money in pursuit of certificates that have no value in the labour market. In agreement to this view, Mwebi and Simatwa (2013) report about the dissatisfaction of the Federation of Kenya Employers on the graduates from private universities. According to him, this body's representatives complained that graduates from private universities were failing to express themselves in their respective fields of study. The same trend was observed in Nigeria. In Ajadi's (2010) study, it was revealed that most of the courses offered in some private universities did not meet the accreditation requirements set by the National Universities Commission (NUC). According to this author, some of the courses were only recognized but not accredited. Since there was no penalty to any university for offering courses not accredited, this made private universities in Nigeria to just introduce courses anyhow (Ajadi, 2010).

In Malawi, the institutions of higher learning in Malawi can only get accredited by the National Council for Higher Education (NCHE) when they have demonstrated that they meet the council's standards for accreditation and comply with its policies (NCHE, 2013). This body was put into existence by the 2011 National Council for Higher Education Act of the Laws of Malawi with the primary purpose of providing "accreditation and quality assurance services in higher education institutions" (National Council for Higher Education [NCHE], 2017). Sections 27 (2) and 36 (3) of the National Council for Higher Education Act in the Laws of Malawi requires NCHE to evaluate higher education institutions whether public or private and their programmes of study for accreditation. In line with its aims and functions, the council developed Standards for Accreditation of Higher Education Institutions in Malawi in 2013, Standards and Guidelines for Quality Assurance in Malawi's Higher Education Institutions, and later the Council developed Minimum Standards for Higher Education Institutions in 2015.

\section{Research methodology}

This descriptive survey study was conducted at the purposively sampled six private universities which were located in Blantyre City in Malawi. These six institutions were selected because they were the only known private universities situated in Blantyre in the Southern Region of Malawi during the time of the study (Kothari, 2007). The study was conducted in the period between the months of January and March of 2018. It involved a total of 152 respondents comprising of three registrars, 10 heads of departments, 23 lecturers, and 96 students from the targeted private universities, as well as 20 public and private sectors executives in the country. This was a $92.7 \%$ response rate $(n=164)$ because three registrars did not return their questionnaires, one university did not have heads of departments at the time of the study, and that some lecturers sampled could not be reached to participate. The public and private sectors executives were included as respondents in this study because they were considered as the users of the universities products in the industry hence their views on the subject were valuable. Simple random sampling was used in 
selecting students and teachers, while the purposive sampling method was employed to select registrars, heads of various academic departments at each university and also public and private sectors executives. Convergent parallel mixed methods design was used to simultaneously generate both quantitative and qualitative data from close and open-ended questions from semi-structured questionnaires which were used on students, teachers and heads of departments, and qualitative data from semi-structured interviews with registrars and public and private sectors executives to tabulate their perceptions on accreditation issues in private universities in Malawi. Brief follow-up interviews with five teachers were also conducted for triangulation purposes. During this study, the qualitative component had greater importance and priority than quantitative one for addressing the study's purpose (QUAL + quan) since the study was so much interested in digging the feelings of the respondents pertaining to the issue under discussion, while the quantitative component had a lesser priority (Creswell, 2014; Plano Clark \& Creswell, 2015). The study put much focus on the narrative description of respondents. In the words of Fraenkel and Wallen (2009, p. 423), the focus was "to know what the participants in a study are thinking and why they think what they do". Hence the researcher needed to "capture the thinking of the participants from the participants' perspective" in their own actual words to respond to the research questions of this study (Fraenkel \& Wallen, 2009, p. 423).

To ensure the reliability of the tools, the "test-retest method" was used, whereby the instruments were administered at the pilot group and re-administered after two weeks on the same groups (Fraenkel \& Wallen, 2009). To ensure the validity of the data in this research, the study used a criterion-related type of validity evidence using concurrent validity. With this one, the researcher compared and triangulated data collected from two or more instruments targeted on different groups such as students, teachers, departments' heads, registrars and external stakeholders. Qualitative data from some parts of questionnaires and interviews were analysed through content analysis and presented in narrative form with specific highlights on three themes on general perceptions of respondents on accreditation issues, their assessment of NCHE's actions and their views on the removal of some universities from the accreditation list. While little quantitative data obtained from some parts of the questionnaires administered to students and teachers was edited, coded, classified and summarized descriptively with the help of the computer statistical software package, SPSS version 22.0 (IBM Statistical Package for Social Scientists), which helped in the descriptive analysis and computation of responses into frequencies, percentages and graph that were used for comparison of the results.

\section{Results}

\subsection{Perception of stakeholders on accreditation issues in private universities}

The university registrars and heads of departments were firstly asked to indicate if the National Council for Higher Education officials had ever paid them a visit at their institution. All of them $(\mathrm{n}=13)$ indicated that NCHE officials indeed visited their universities ranging from once, twice and even more than twice. Still more, $55 \%$ of these registrars and heads of departments indicated that they were not threatened by the NCHE officials' visits since the council's assessments were crucial for the legitimacy of their institutions' existence in the country. Additionally, they opined that NCHE was there to look out for students' interests. However, the remaining $45 \%$ indicated that they were threatened since the presence of NCHE officials at an institution created uncertainty and tension amongst lecturers as well as students regarding the final verdict from their reports. Some of them had this to say:

"NCHE officials visits is never usual, it always brings tension and uncertainties at an institution to both members of staff and students. To students, it is like a high court sentence to their future in the background that they had already spent a lot on their education; rejecting accreditation of their university could mean their loss. But also members of staff are usually uncertain regarding their employment future. It is not a good time I tell you." (One of the three registrars) 
The Accreditation Issues of Private Universities in Malawi

"Even the mere rumour that those NCHE officials are coming to assess your institution and its programmes temporarily disrupt education. You would find bosses in the high offices moving up and down, making sure that everything is in place. They are even tempted to stage some things in the library, computer laboratories and even in classrooms. I remember one time our registrars telling me to look for an overhead projector set to be put in one of the classrooms as a show, imagine that." (One of the Heads of the Academic Departments)

In a follow-up interview with five teachers in these universities, all of them agreed that there is always tension when NCHE official visits a private institution of higher learning. This is what one of the teachers said;

"Let me not lie here, there is always an air of tension lingering when the NCHE guys visit a university especially like this university which does not have enough required resources. Imagine I am a part-time lecturer, I work on an hourly rate, but the registrar couched me and my fellow teachers to indicate that I am a full-time member of academic staff if I happen to secretly be asked by those visiting NCHE officials, all to try to create a good impression. Fortunately, they never asked anybody, they only had a meeting with the executives. There is too much pretence and lying when the NCHE guys are visiting. I suggest they visit unannounced to catch these rogues red-handed".

On the same note, students, teachers and registrars involved in this study were further asked to indicate if they thought that their universities had problems with National Council for Higher Education (NCHE). Figure 1 illustrates their responses.

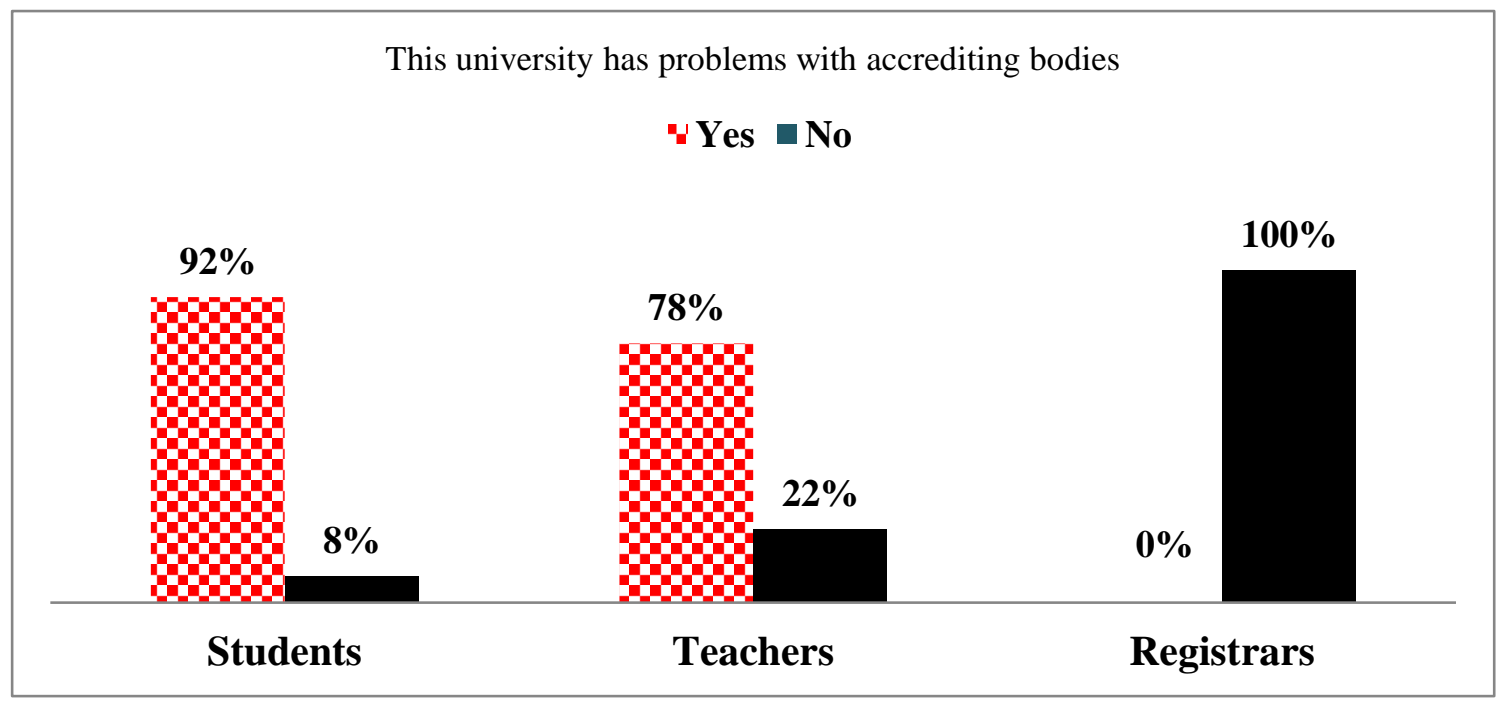

Figure 1: Students, teachers and registrars' responses to the accrediting question

Figure 1 shows that the majority of students, teachers and heads of departments of six private universities involved in this study reported that private universities had problems with the accrediting body. The graph shows that $92 \%$ of students $(n=96)$ and $78 \%$ of teachers $(n=23)$ indicated that their universities had problems with accrediting bodies; while in contrast, all three registrars involved in this study indicated that they did not have problems with the accrediting bodies. However, upon verifying the issue with the external stakeholders involved in this study (government and private sectors officials), they all agreed that these universities had problems with NCHE since it was all over the newspapers and on radios that some of these universities or their study programmes were continuously discredited or removed from the list of accredited institutions or study programmes for failing to meet some set requirements.

These sentiments by these respondents concur with what this study found which was earlier published by the same author (Kajawo, 2019). Based on the results of the study, it was concluded that though the 
emergence of private universities in Malawi was to some extent contributing to the development and expansion of higher education opportunities to many Malawians, the quality of higher education offered left a lot to be desired particularly due to the inadequacy of qualified academic staff in most of the private universities since the institutions were failing to attract enough them because their remuneration package offers were not motivating enough. The study found that $29.3 \%(n=184)$ of lecturers in these universities were holders of bachelor's degrees, teaching students pursuing a bachelor's degree as well. Worse still three heads of departments which were involved in this study $(\mathrm{n}=10)$ were bachelor's degree holders; obviously, they were also teaching. $87 \%$ of teachers in this study $(\mathrm{n}=23)$ complained that their salaries were very low as compared to their colleagues working in public universities, hence cited this as the reason many teachers were unable to stay in one private university employment for a long period was since every one of them with a master's degree or $\mathrm{PhD}$ was always looking for a vacancy at one of the public universities in Malawi. This was making these institutions to fail to retain and attract top-quality teachers.

Quality was also compromised by the lack of other resources such as finances and physical resources in the form of suitable academic facilities such as libraries and laboratories as well as the equipment and materials. More than $70 \%(\mathrm{n}=119)$ of teachers and students in this study indicated that their universities did not have adequate textbooks in the libraries, computers for use by students, free accessible internet, access to online learning resources such as e-journals, extra-curricular resources such as sports equipment, gym halls, sports grounds, laboratory and other technical learning tools/resources. As a result of all these challenges and hiccups, education quality was compromised since teaching in these universities was too much focused on theoretical knowledge rather than practical, and that little emphasise was given to research and innovation. These were issues that NCHE officials would not smile at.

\subsection{How stakeholders assessed NCHE's actions in exercising its mandate}

The majority of students, teachers and heads of department (more than $60 \%$ of $n=129$ ) indicated that NCHE was too much strict and unfair to the private universities since they were making many Malawians to lose trust in them thereby withdrawing their enrolments in those institutions with the belief that they were offering low-quality education. They said this citing the-then latest NCHE Press Release of February 2018 in which the body de-registered nine private universities and forced them to close their institutions in Malawi with immediate effect (NCHE, 2018). According to teachers, students as well as some public and private sectors' officials, this was enhancing the negativity in terms of quality that, for a long time, has been associated with private universities. They argued that private universities were not considered as first choices for the students' as well as parents' decisions of proper university due to essentially the outcomes of NCHE's assessments. According to the heads of departments, private universities were already disadvantaged in the competition; since public universities had good reputations established over the years coupled with government funding that enabled them to charge low fees thereby able to attract applications and enrolments from the cream of students even beyond their capacities. This was what one of the external stakeholders, who was educated at one of the private universities had to say:

"The general notion that people consider private institutions to be a substitution for public institutions is already a problem. Hence, they are considered less important and only relevant where public universities' capacity for selection is not sufficient. When people consider private institutions as a secondary option, it lowers morale in many who in turn effortlessly strive to find

a place in public institutions for years, sometimes without succeeding".

According to many students interviewed in this study, most of them never planned to study at their current private institutions since their first choices and only wish was to be selected at one of the public universities in Malawi. But they had no choice but to apply for a place at their existing private universities after failing to secure a place at their favourite public universities. This, according to one private sector official was partly caused by the negative picture that the quality assurance and monitoring agency, the Malawi National Council for Higher Education was putting in the media about private universities in Malawi. According to him; 
"Delayed accreditation or recognition by the National Council for Higher Education of Malawi (NCHE) of the private higher education institutions is already bad publicity. When institutions are not recognized by government regulatory arm it becomes difficult for people to trust their credibility. Private institutions are not as popular as public universities, and this affects the ability for prospective students to locate them. Sometimes these institutions have a great room to accommodate for many students but due to lack of good publicity, some prospective students just loathe in locations [at home] with nowhere to go to further their education".

However, some public and private sectors' executives had a different view. According to them, the National Council for Higher Education of Malawi (NCHE) was justified in excising its duty of monitoring and assuring quality in private universities. This is what some of them said.

"I salute NCHE for the job well done. If not all necessities are met, it is not good for a university to start teaching otherwise quality and standards would be compromised. This would also give other universities some seriousness on handling academic issues. NCHE's efforts will also contribute to the credibility of our higher education system nationally as well as internationally". "The decisions were justified as they are within law and practice. There is no alternative to strict compliance with NCHE guidelines if Malawi is to improve the quality of education. This is despite thousands of students affected by the decision".

"Most of these private universities are established to make profits. Therefore, concentration dwells on the profit-making instead of putting more effort in the managing of academic necessities e.g school blocks libraries, cafeteria toilets and bathrooms, hostels and qualified lectures".

Some of the public and private sectors' executives observed that as much as NCHE was justified to discredit some of the universities, the accrediting body was not proactive but rather reactive in controlling the quality of higher education in Malawi:

"NCHE as a government arm regulating higher education is justified to remove, retain and return private institutions based on the gravity of shortfalls identified. However, it is regrettable that sometimes NCHE is not proactive enough to curb some problems with private universities in their virgin phases hence the justification may be quashed if NCHE delayed to take action and advise the responsible universities timely...".

"The problem is that NCHE just looks the other side when they see these universities starting their operations even before registering with the council. They still wait when these unregistered, unaccredited institutions are even advertising publicly their institutions for enrolment in the media. They later on, upon their applications, tell them that they have failed the accreditation. This is unfair to the students. The body needed to be so strict as not allow any institution to start operating before registration and accreditation of both the institution and the offered study programmes".

\subsection{The stakeholders' views on the impact of NCHE's removal of some universities on the list of accredited institutions}

This study was also interested to know how the accrediting body's action of removing some of the universities on its list of accredited universities affected the perceptions, confidence and feelings of the public and private sector executives, as external stakeholders of these private universities. All executives involved in this study $(n=20)$ admitted that NCHE's actions had an impact on the way they felt about the concerned universities, students and produced graduates. According to them, it was difficult to trust their certificates for employment since they were generally perceived as half-baked graduates who received an education of very low quality. The following were some of these executives' responses.

"I felt that the qualifications of these fellow employees were irrelevant and not up the standard.

When we were employing some staff to fill in our vacancies, we were forced not to include or 
shortlist some individuals with those degrees for job interviews as their qualifications were doubted".

"Somehow, I thought they have been half baked more especially those that did courses that were banned. However, for those colleagues who perform better despite NCHE's issues, I still salute and respect them".

"It all goes to the first point I made on the council being proactive. The council is justified to remove or reject institutions or programmes of study for accreditation. But then, for those just starting, this ought to be even before those institutions have enrolled and admitted students. NCHE is there partly to protect the interests of citizens, in this case, protecting the unsuspecting Malawians seeking higher education from the vultures masquerading as universities by putting efforts to even have them prosecuted in the courts of law".

\section{Discussion}

This article presents and analyses the perceptions of key stakeholders of private universities in Malawi on issues of accreditation. From this study, it has been noted that many stakeholders were of the view that Malawi National Council for Higher Education was doing a commendable job in providing the needed monitoring and evaluation of higher education institutions and study programmes in Malawi. In other African countries, it was observed that the growth in the number of private universities also awakened governments to set control and monitoring measures through regulation bodies, just like NCHE, to oversee the accreditation, quality control and licensing processes of private universities in their respective countries (Mande, 2006; Ochwa-Echel, 2016; Seniwoliba \& Yakubu, 2015). For instance, Seniwoliba and Yakubu (2015) concluded in their study that quality assurance took firm root in universities in Ghana after the establishment of the National Council for Tertiary Education and the National Accreditation Board.

However, despite having these regulatory bodies in place, studies revealed that most higher education accrediting agencies in many African countries were not exercising their roles effectively. For example, in Uganda, Ochwa-Echel (2016) failed to understand how some private universities received accreditation without charters as per the requirement of NCHE. In Kenya and Nigeria, it was reported that private universities were enrolling students into study programmes that were not accredited by their countries' accrediting agencies, and yet there was no any tangible action by the respective countries' commissions (Gogo, 2010; Ajadi, 2010). The Malawi universities accreditation body was exercising its powers and responsibilities efficiently by providing frequent monitoring, control and assessments on all universities in Malawi to ensure that there were not compromising on the general quality of higher education in the country.

It was also noted that the NCHE's visits created a certain amount of tension amongst lecturers, students and even registrars of those universities regarding their future. This was because the act of not being credited or deregistered had a very frightful impact on the reputation of the concerned universities, students and the already produced graduates. This has always been expected even in western countries. In Europe, Scheele (2004) used the metaphor of James Bond's movie titled "Licence to Kill" to refer to the accreditation phenomenon to show how accreditation was feared by almost all concerned individuals. Scheele argues that the national councils for higher education are compulsory quality assurance systems for the institutions set by governments which, in Bond terms, are able "to scare the living daylights out of..." the concerned institutions if they are not meeting the given conditions (Scheele, 2004, p. 23).

The study, therefore, found that the accreditation of institutions of higher learning, as well as their programmes of the study was very important. It does not make sense that entrepreneurs would want to venture into higher education provision businesses without ensuring quality. It is not right for them to decide to open universities without enough academic staff, facilities and other resources thereby playing around on innocent young people's futures. An institution of higher learning is not cheap to establish (Altbach \& Salmi, 2011), that is why even many African governments are failing to open as many universities as possible in their countries. Universities, whether public or private, just need to be characterized by quality 
and excellence, equity, responsiveness and effective and efficient provision of services, good governance and excellent management of resources (Chacha, 2002). Higher education institutions require, among other things, physical facilities befitting higher education standards with good teaching spaces, libraries, and laboratories, as well as sophisticated information technologies. The proprietors need to have enough funds and investments to offer high-quality education to people in order not to be tensed by the presence of NCHE's officials.

Based on these findings, the study suggests the following. Firstly, the Malawi Government through its monitoring agency, National Council for Higher Education (NCHE) needs to be applauded for its diligence in the monitoring and controlling the quality of higher education in Malawi. Nevertheless, Malawi Government should revise the Higher Education Policy in the country to strongly include a requirement that private universities should only start operating after duly and fully registered and accredited by NCHE to avoid the situation in which universities were closed due to not meeting the standard requirements after operating for a while; consequently academically affecting the students who were enrolled in those universities as a result of wasting their money and time. It does not make sense why individuals would want to open an institution of higher education as a business without fully investing in resources befitting the standards of a university. The institutional accreditation ought to provide a licence to operate based on an evaluation of whether the institution meets specified minimum standards (Harvey, 2004). This follows that in principle, an institution ought not to start operating before obtaining this licence. As it was during the time of this study, there was a provision in NCHE's Act on Section 19 (No. 5 of 2011) that required that private universities should not start admitting students or commencing operations in Malawi until registered and getting study programmes accredited, and that any violation of such law was punishable by a fine and a maximum of 14 years of imprisonment (Section 34 of the NCHE Act). Nonetheless, some private universities were operating and had students admitted in unaccredited programmes of study. The provision seemed toothless, hence needed to be given much reinforcement in terms of punishment of the defaulting institutions to enhance deterrence and compliance. The current rate of emergence of new private universities in the country, if not properly checked and controlled, is alarming and dangerous. It could lead to a situation in which unregistered and unaccredited universities continue to operate as "degree mills" hence continuing producing graduates that are not fully educated, unproductive as well as unemployable. Further to that, the higher education policy and the law should be revised to also give absolute power to NCHE to use all necessary means to close all universities that fail the annual or periodic evaluations to strengthen compliance to the minimum requirements provided in the Minimum Standards for Higher Education Institutions (2015) policy. As it is now, even though the universities are discredited, they are left to continue operating with the hope that they would be improving in issues which were noted in the evaluation reports. The universities are forced to close only if they are deregistered. This was the reason why many students complained in this study that they were not sure of their future at their universities because of the fear of being discredited. Therefore, NCHE needs to be given the power to immediately close those universities that have been evaluated to be below the required standards to make these universities proactive in maintaining the highest standards at all times. This was because having a few highquality institutions was better than having plenty "degree mills" masquerading as "universities".

Lastly, NCHE should also regularly update their website that provides information about all universities operating in Malawi. This study found out that information about universities in terms of their enrolment totals, facilities as well as the quality of education they were providing were scarce hence prospective students, parents and guardians were relying on particular universities prospectuses and websites, of which could be unreliable sources of that kind of information. Creation of the database or making detailed information especially about private universities accessible would assist the public to gain knowledge about the strengths and weakness of such universities, as well as help them to make decisions about which universities to enrol their children or wards, hence never regret in the future. The said database needs also to include the column of all institutions that are operating illegally before registration and accreditation. During the time this study was conducted, NCHE was only able to list those institutions that were duly 
assessed in its press statements in those categories of accredited, non-accredited, deregistered and rejected. NCHE needs to also raise a red flag on those universities operating before accreditation or registration. This is because most of them create websites or blog pages that misinform their potential students that they are accredited or registered by NCHE and other international accreditation organisations when in true sense they are not yet, only that they might have just applied for registration or accreditation. One, therefore, wonders why NCHE is not doing anything. It is high time that NCHE needed to be very serious on higher education standards to protect Malawians from unscrupulous businessmen masquerading as academicians. The results presented in this paper cannot be widely generalised. The article was mainly based on qualitative data collected in the study from the narrative description of respondents, of which collection of biased views was unavoidable. However, the effect of this limitation was partly mitigated by triangulations which were done on data collected from different kinds of respondents as well as from the use of quantitative statistical tabulation of frequencies and percentages to augment general results.

\section{Conclusion}

Quality assurance and monitoring in higher education institutions especially privately owned ones ought to be an essential function and not neglected or considered as a luxury by the government in the provision of education to all the citizens. The findings of the study reveal that NCHE was doing a commendable job in assuring the quality of higher education in Malawi in its responsibility of monitoring and evaluating universities, especially privately-owned ones as well as their programmes of study. However, the study noted some challenges in the way this accreditation body was operating. The first one was that it was reported that many private universities were not fully accredited but were still operating thereby offering study programmes which were not evaluated. It was also noted that NCHE did not have absolute power of closing all universities that fail the annual or periodic evaluations to strengthen compliance to the minimum requirements, since during the period of the study, even though some universities or some of their programmes of study were rejected accreditation, they were continuing operating. The universities were forced to close only if they were deregistered. This was why many students complained in this study that they were not sure of their future at their universities because of the fear of being discredited. Nonetheless, the study concluded that the accreditation of institutions of higher learning, as well as their programmes of study, was the only way to go in enhancing and controlling the quality of higher education in Malawi since there is no alternative to strict compliance to high standards.

\section{Declarations}

\subsection{Acknowledgements}

My heartfelt gratitude goes to the Government of the People's Republic of China for the sponsorship opportunity, my Supervisor, Professor DONG, Xiuhua and the Faculty of International Centre of Teacher Education (ICTE) of ECNU for their support and to all registrars of six private universities for their permission for this study.

\subsection{Funding Source}

The research that resulted in this article was funded by the stipend allowances provided with the Chinese MOFCOM Scholarship. There was no direct funding to the research.

\subsection{Informed Consent}

Questionnaires and other instruments included an area and a form on which all respondents were requested to give their consents to participate in the study after explaining to them in languages they could understand the content of the form as well as the purpose and procedure of the study.

\subsection{Competing Interests}

The authors declared that no conflict of interest exists. 


\section{How to Cite this Article:}

Kajawo, S. C. R., \& Dong, X. (2020). The Accreditation Issues of Private Universities in Malawi. Advanced Journal of Social Science, 7 (1), 125-137. https://doi.org/10.21467/ajss.7.1.125-137

\section{References}

Ajadi, T. O. (2010). Private universities in Nigeria: The challenges ahead. American Journal of Scientific Research, 7, 15-24. http://www.eurojournals.com/ajsr.htm

Akpotu, N. E. \& Akpochafo, W. P. (2009). An analysis of factors influencing the upsurge of private universities in Nigeria. Journal of Social Sciences, 18(1), 21-27. https://doi.org/10.1080/09718923.2009.11892663

Altbach, P. \& Salmi, J. (Eds.). (2011). The road to academic excellence: The making of world-class research universities. The World Bank.

Amponsah, E. B. \& Onuoha, L. N. (2013). The performance and challenges of private universities in Ghana and Nigeria. International Journal of Business and Social Science, 4(5). http://www.ijbssnet.com/journals/Vol_4_No_5_May_2013/30.pdf

Chacha, N. C. (2002, April 25-27). Public universities, private funding: The challenges in East Africa. [Paper presentation]. International Symposium on African universities in the 21st Century, University of Illinois, Urban Champaign.

Chimombo, J. P. A. (2003). Malawi: In P. Altbach \& D. Teffera (Eds.), African higher education (pp.141-421). Indiana University Press.

Chivwara, N. (2013). An analysis of the governance of higher education access in Malawi (Master's thesis, University of the Western Cape, Western Cape, South Africa). http://etd.uwc.ac.za/xmlui/handle/11394/4039

Creswell, J. W. (2014). Research design: Qualitative, quantitative, and mixed methods approaches (4th ed.). SAGE Publications.

Fraenkel, J. R. \& Wallen, M. E. (2009). How to design and evaluate research in education. (7th ed.). McGraw-Hill.

Garwe, E. C. (2015). Quality assurance challenges and opportunities faced by private. Journal of Case Studies in Education, 3(2), 26-31. http://www.macrothink.org/journal/index.php/ire/article/view/7288/6205

Gogo, J. O. (2010, August 26-28). The development of university education in Kenya: The problem of human resource in private universities. [Paper presentation]. EMSK Conference, Kabarak University, Kenya.

Gomile-Chidyaonga, F. (2003). Encouraging greater enrolments of women in science and technology: The Malawi Polytechnic experience. https://pdfs.semanticscholar.org/4d5d/1b3e34f372f26e7f27b50df9e8e198202651.pdf

Harvey, L. (2004). The power of accreditation: Views of academics. In P. D. Nauta, P. Omar, A. Schade \& J. P. Scheele (Eds.), Accreditation models in higher education. Experiences and perspectives. ENQA workshop reports 3 (pp. 5-18). European Network for Quality Assurance in Higher Education. https://enqa.eu/indirme/papers-and-reports/workshop-and-seminar/ENQAmodels.pdf

Hayward, F. M. (2006, June 13-15). Quality assurance and accreditation of higher education in Africa. [Paper presentation]. The Conference on Higher Education Reform in Francophone Africa: Understanding the keys of success, Ouagadougou, Burkina Faso.

Hunter, F. J. (2009). Evolutionary sagas of three private universities in Italy: Critical factors in developing institutional responsiveness to exogenous change (Doctorate thesis, University of Bath, Claverton Down, Bath, United Kingdom).

Kajawo, S. C. R. (2019). Examining performance and challenges of private universities in Malawi. International Journal of Research and Innovation in Social Science, 3(6), 48-58. https://www.rsisinternational.org/journals/ijriss/Digital-Library/volume-3-issue-6/4858.pdf

Kothari, C. R. (2007). Research methodology: Methods and techniques (2nd ed.). New Age International Publishers Labour Law Journal, 58(91), 47-52.

Lenn, M. P. (2003). Strengthening World Bank support for quality assurance and accreditation in higher education in East Asia and the Pacific. World Bank.

Lunenburg, F. C., \& Ornstein, A. C. (2012). Educational administration: Concepts and practices. (6th ed.). Wadsworth Cengage Learning.

Lyamtane, E. C. (2013). Assessment of the implementation of Inter-University Council for East Africa quality assurance guidelines in faculties of education of chartered universities in Tanzania (Doctoral dissertation, The Catholic University of Eastern Africa, Tanzania).

MacJessie-Mbewe, S. (2009, October). Domesticating alternatives to neo-liberalism in Southern Africa: Implications for Malawi's educational process, in domesticating alternatives to Neo-liberalism in Southern Africa in Malawi [Paper presentation]. National Policy Workshop on a Review of free market policies.

Mande, W. M. (2006). Management of private universities in Uganda. http://www.academia.edu/30769972/Management_of_private_universities_in_Uganda

Mapolisa, T. (2015). A comparative case study of Zimbabwe's public and private universities'staff retention strategies. (Doctoral thesis, Zimbabwe Open University, Harare, Zimbabwe). https://www.slideshare.net/nathson/staff-retention-strategies-in-zimbabwespublic-and-private-universities-returnee-lecturers-perspective

Maruyama, F. (2008). An overview of the higher education system in Japan. The Journal of Finance and Management in Colleges and Universities, Special Edition, 1-12. http://www.zam.go.jp/n00/pdf/nk001001.pdf

Mbirithi, D. M. (2013). Management challenges facing Kenya's public universities and implications for the quality of education (Kenyatta University, Nairobi, Kenya). http://ir-library.ku.ac.ke/bitstream/handle/123456789/7030

Muheya, G. (2016, November 18). Malawi deregisters African University that awarded Minister Kaliati doctorate degree: 5 colleges not accredited. Nyasa Times. https://www.nyasatimes.com/malawi-deregisters-african-university-awarded-minister-kaliati-doctoratedegree-5-colleges-not-accredited/

Mwebi, B. \& Simatwa, E. M. W. (2013). Expansion of private Universities in Kenya and its implication on quality and completion rate: An analytical study. International Research Journals, 4(4), 352 - 366. http://www.interesjournals.org/ER

National Council for Higher Education [NCHE]. (2017). http://www.nche.ac.mw/index.php/about-nche/functions

National Council for Higher Education. (2013). Standards for accreditation of Malawi's higher education institutions. http://www.nche.ac.mw/documents/standards_for_accreditation.pdf

National Council for Higher Education. (2017). Highereducation in Malawi. http://www.nche.ac.mw/ 
Samson C. R. KAJAWO \& Xiuhua DONG, Adv. J Social Sci.; Vol. 7, Issue 1, pp: 125-137, 2020

National Council for Higher Education. (2018). Registered institutions. NCHE. http://www.nche.ac.mw/index.php/resources/registeredinstitutions

National Council for Higher Education. (2019). Registered and accredited higher education institutions in Malawi. NCHE. http://www.nche.ac.mw/downloads/Accredited_Institutions_\&_Programmes_26052020.pdf

National Council for Higher Education. (2015). National council for higher education minimum standards for higher education institutions. http://www.nche.ac.mw/documents/minimum_standards.pdf

Nur-Awaleh, M., \& Mtegha, D. (2005). Shared governance and leadership in African universities: Experiences from Mzuzu University, Malawi and Amoud University, Somaliland. Africa Journals Online, 30(1), 34-52. https://doi.org/10.4314/ad.v30i1.22211

Nyondo, P. (2015, August 7). Malawi accredits universities of Nkhoma, Daeyang - Western University of Blantyre rejected. Nyasa Times. http://allafrica.com/stories/201508080154.html

Ochwa-echel, J. (2016). Private universities in Uganda: Issues and challenges. International Journal of Education and Social Science, 3(3). https://works.bepress.com/james_ochwa-echel/5/download/

Onsongo, J. (2007). The growth of private universities in Kenya: Implications for gender equity in higher education. Council for the Development of Social Science Research in Africa, 5(2\&3), 111-133. https://www.codesria.org/IMG/pdf/5-onsongo5-2-2007.pdf

Plano - Clark, V. L., \& Creswell, J. W. (2015). Understanding research. A consumer's guide (2nd ed.). Pearson Education.

Scheele, K. (2004). Licence to kill: About accreditation issues and James Bond. In P. D. Nauta, P. Omar, A. Schade \& J. P. Scheele (Eds.), Accreditation models in higher education. Experiences and perspectives. ENQA workshop reports 3. (pp. 19-25). European Network for Quality Assurance in Higher Education. https://enqa.eu/indirme/papers-and-reports/workshop-andseminar/ENQAmodels.pdf

Seniwoliba, J. A. \& Yakubu, R. N. (2015). An analysis of the quality assurance policies in a Ghanian University. Educational Research and Reviews, 10(16), 2331-2339. https://doi.org/10.5897/ERR2015.2425

Shankar, A. (2016). Role of private sector in higher education. http://www.prsindia.org/administrator/uploads/general/1453203086_Role\%20of\%20Private\%20Sector\%20in\%20Higher\%20Edu cation.pdf

Shawa, L. B. (2014). The quest for a quality delivery of university education in Malawi. Mediterranean Journal of Social Sciences, 5(20), 1176-1183. https://doi.org/10.5901/mjss.2014.v5n20p1176

Suleiman, Y., Hanafi, Z. B., \& Tanslikhan, M. (2017). Private universities and development of higher education in Nigeria: A mixed methods approach. The Qualitative Report, 22(7), 1848-1879. http://nsuworks.nova.edu/cgi/viewcontent.cgi?article

Tibarimbasa, A. K. M. (2010). Factors affecting the management of private universities in Uganda (Doctoral dissertation, Makerere University, Uganda). https://www.mak.ac.ug/documents/Makfiles/theses/Tibarimbasa_Avitus.pdf

Uganda National Council for Higher Education (2011). Quality assurance framework for universities and the licensing process for higher education institutions. National Council for Higher Education.

World Bank. (2009). Malawi education country status report: CSR 2008/09. World Bank. 